\title{
A Study on Satisfaction of the Busan Dragon Boat Race Using Natural Tourist Attractions
}

\author{
Kwi-Baek Kim ${ }^{1}$, Jae-Young Park ${ }^{2}$, Hwa-Yeol Choi ${ }^{3, *}$ \\ ${ }^{1}$ Department of Marine Leisure Tourism, Youngsan University \\ ${ }^{2}$ Sea Explorers of Korea Busan Council. \\ ${ }^{3}$ Department of Aviation Service Management, Jeju International University. \\ demi100@ysu.ac.kr; Sek5955@naver.com;: hwayeol@hanmail.net
}

\begin{abstract}
The purpose of this is to investigate the satisfaction of various physical environmental factors of the competition using natural tourist sites recognized by the dragon boat participants held at the Suyeong River APEC Park in Haeundae, Busan, and discuss ways to utilize natural tourist sites. This study explores the physical environmental factors satisfied by athletes participating in the dragon boat competition held in a water-friendly space, and analyzes differences according to participation level and participating nationality to identify differences in physical environmental factors according to the athletes participating in the competition. Proceeded. It is believed that it can be extended to research on the dragon boat competition held in a water-friendly space, the suitability of the local space, and the expected effects of the local community through the event.
\end{abstract}

Keywords: Dragon Boat festival, Sport event management, Service Satisfaction. 


\section{Introduction}

Dragon boat is a dynamic water sports sport where 12 people and 22 people usually board the boat and take on the roles of rowers, helmsmen, and drummers. Since it was adopted as an official event in the 2010 Asian Games in Guangzhou, the number of hobbyists has increased globally beyond Asia. Lee and Lim (2019) said that the Dragon Boat Festival as a part of leisure activities in marine sports has a great potential that it can be used as a tourism element in the region as a water leisure sport and cultural content. The dragon boat competition has the characteristics of using a waterfront or waterside area, a surface of water, and a water's edge in a wide variety of ways. It is very free of access and has the characteristics of a place that can attract many people's attention with an image that is closer to leisure than sports, and due to its original nature, it can be conducted in conjunction with local festivals throughout the event (An, 2016).

Waterfront refers to a site in contact with water in a dictionary, a building built on the site, or, in a larger sense, a part of a city connected with water. However, somewhat different from the dictionary meaning, the waterfront is generally used as including the concept of a city or a resort. In other words, even if the scenery is good, a space where people can visit is not called a waterfront, and a place where various facilities are located and attracts many people is called a waterfront in a true sense. The natural tourist spot is understood to be a space where local residents can relax, relax and enjoy sports activities. As a result, discussions on the use of space have been brisk recently, with the development of local landscapes, festivals and various recreational activities taking advantage of these natural tourist attractions. The world-famous tourist and resort cities of Switzerland and France, including Leman, Geneva, Lausanne, Montreux and Evian, are also becoming urban spaces utilizing waterfront, making them people enjoy shopping, healing and leisure (Lee, 2010). Waterfront is a waterfront where people are friendly with water, and these water functions and elements can be distinguished differently by purpose and function, and the reference point can be interpreted as a positive effect for human physiology and psychological reasons. For example, walkways, rest areas, benches, etc. set up in the waterfront provide landscape and psychological stability functions as a place for relaxation and communication, while boat moorings, fishing, ponds and waterfalls also provide recreational functions such as water play and boat experience (Kim and Choi, 2010).

Recently, it means waterside spaces where residents and visitors can enjoy the ocean, such as rest areas. We are trying to organize and spread various experience events. As a representative example, an international dragon boat was held in waterfront areas such as the Suyeong River, the Han River in Seoul, and the Ara Waterway in Gyeongin. At the same time, a new type of female family was introduced to enjoy dragon boats, marine kayaks and paddleboards using local waterfront in various places. Therefore, the concern of the point of view, which can 
explore the necessary factors for dragon boat competitions held in the waterfront and provide the benefits of local residents and participants, is considered a very important factor in terms of utilization of the waterfront and activation of the dragon boat.

For this reason, it is necessary to look at various sports events held in consideration of the local environment. In general, sports events strive to create direct and indirect economic effects for the region (Kim and Cho, 2014) by promoting regional development, building and enhancing local image, and promoting residents' benefits and benefits. In particular, there is a stereotype that sports events are relatively easy to access compared to events in other content, and that the effect is expected to be high due to the high acceptability of unspecified inmates (Min et al., 2020). However, rather than holding unconditional sports events, it is necessary to carefully check the actual connection of contents suitable for the region, discussions with local residents on the effects of holding events, benefits of hosting events (such as the number of participants, the number of tourists and the economic effects) and expected inducement factors to achieve the final benefits that the event organizer wants to achieve.

Therefore, the search for factors that can satisfy the first beneficiary of the event is an essential effort for successful event hosting. Above all, the dragon boat competition is an event held using water-friendly space, and it is possible to create environmental satisfaction factors such as location where participants can sympathize with, connectivity and harmony of physical factors of the competition, and needs event characteristics that reflect such phenomena, event characteristics, and event components that take into account participants. This is because the physical environment of the venue considering the venue and the characteristics of the competition are very important (Carman, 1990 and Dabholkar, 1996).

Therefore, in this study, the physical environmental factors of the competition reflecting the characteristics of dragon boats were analyzed according to the level and nationality of the participants. This is meaningful in that it utilizes the space from a more advanced point of view and provides basic data to prepare and expand elements that can satisfy the participants.

Detailed research questions for achieving these research objective are as follows:

Research question 1: What are the factors of the competition's environmental satisfaction perceived by the Dragon Boat Race participants in the waterfront?

Research question 2: What are the differences between the light and light factors of the competitors in the waterfront dragon boat competition?

\subsection{Busan International Dragon Boat Overview}

In the 2019 Korea Open International Competition, 24 Dragon Boat Club teams from 10 countries including Guam, Hong Kong, and Russia participated, and on September 6, the first day of the competition, a 12-seater, 22-seater $200 \mathrm{~m}$ race and 
an extra-curricular kayak competition were held. On September 7th, 12- and 22seater $500 \mathrm{~m}$ preliminaries were held, and on the 8th, the last day, the 12-seater, 22 seater $500 \mathrm{~m}$ final and $1,000 \mathrm{~m}$ race were held. For the success of local sports events or sports events organized by specific organizations, it is very important to find the attractive factors of events recognized by actual consumers, maintain or improve them, and search for factors that can satisfy them. The attractive factor of a sporting event is a phenomenon that attracts consumers who participate in and experience the event due to various environmental stimuli experienced at the event, and can be understood as a factor that causes it (Ko and Park, 2011). Recently, sports events are changing and diversified beyond traditional sports. In particular, local governments and several associations are holding sports events by utilizing the sea, river, and local environment, expecting industrial effects [10]. Above all, sports events and festivals have a significant impact on local lodging and local economy, so the sports events held and local characteristics should naturally match. Among sporting events, water sports are considered to use the natural environment, but safer operation of competitions is considered as a very important factor. For this reason, dragon boats, which take place in waterways with slow flow and calm water, are relatively safe and have no injury compared to other water sports events. Dragon boats, often called dragon boats, are a game in which one team padds forward to match the drums of a drummer, and has a characteristic that shows the importance of unity and training of sports teams (Choi and Ok, 2011). Moreover, it is necessary to respond to changes from the point of view that the players for participation in the competition are exposed to various cultures as well as the region at the time the international competition is being invited.

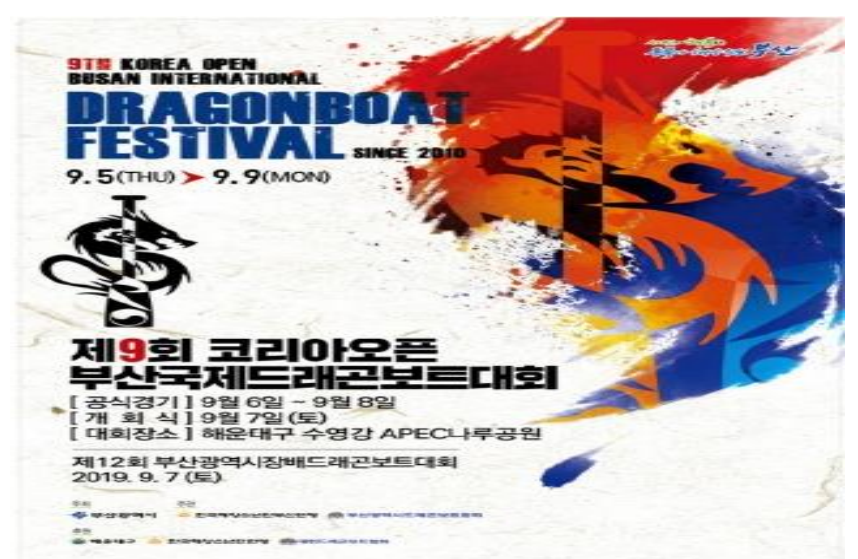

Fig. 1: Busan international dragon boat competition poster 


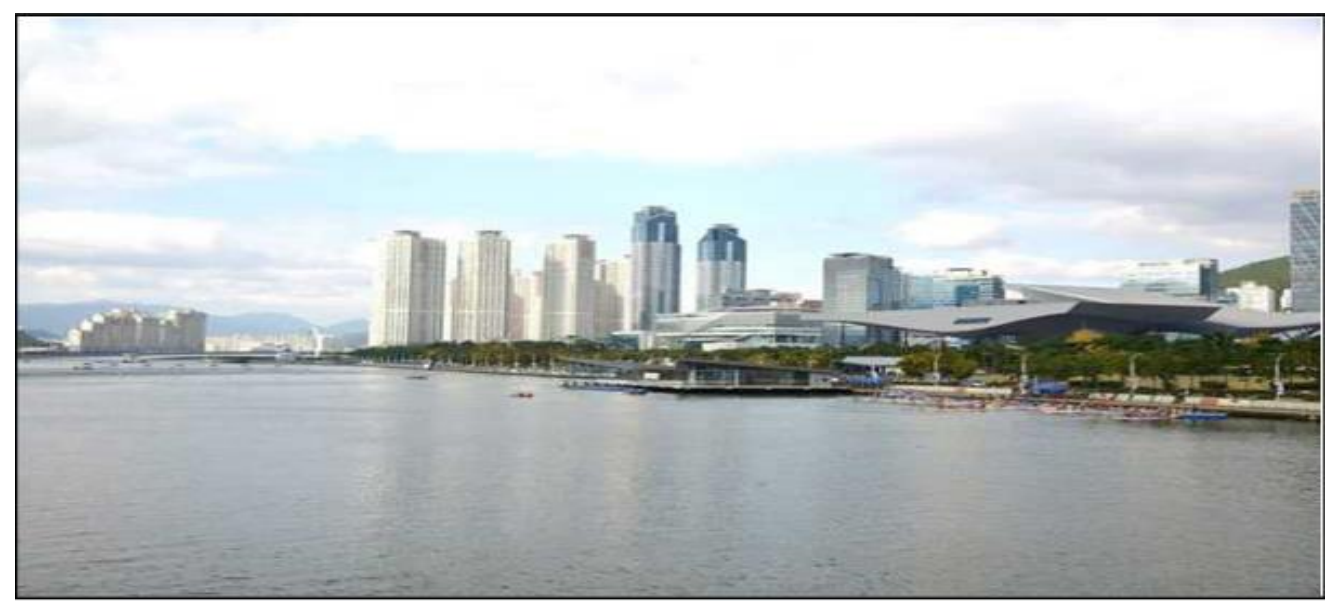

Fig. 2: Busan international dragon boat stadium 1

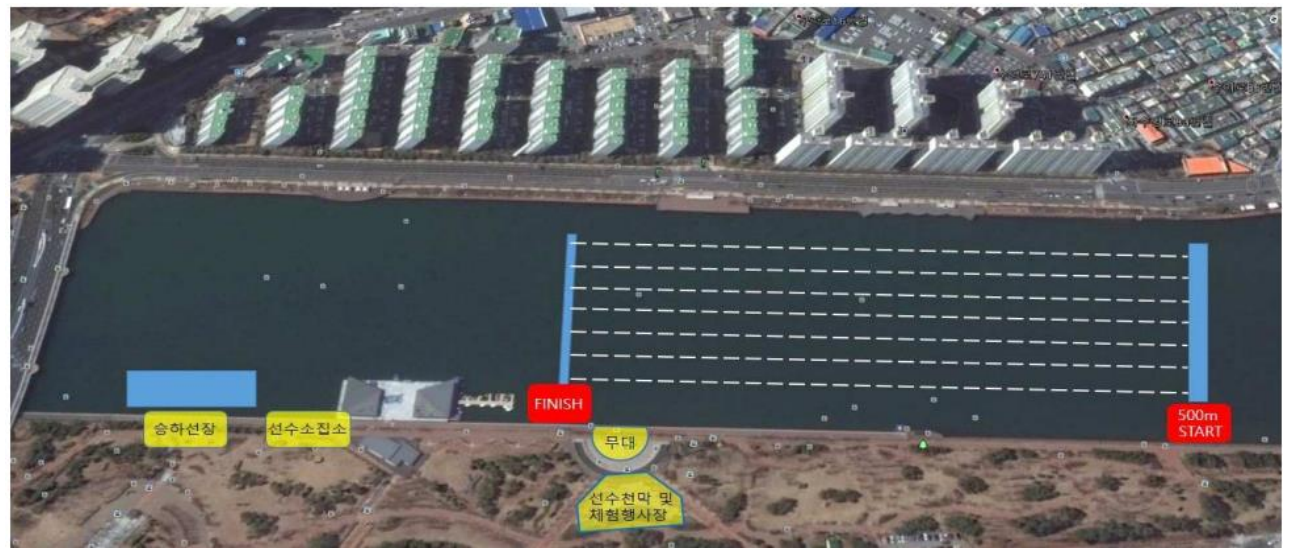

Fig. 3: Busan international dragon boat stadium 2

\subsection{Busan International Dragon Boat Rules}

This event complies with the competition rules and regulations of the World Dragon Boat Federation and the Korea Dragon Boat Association. Exceptional competition rules and competition rules may apply at the discretion of the organizing committee.

\subsubsection{Competition Equipment}

Dragon Boat - 12-seater (Standard: IDBF Champion DB 912 Model) provided by the organizer. Provided by the organizers of paddles and life jackets.

\subsubsection{Team Composition}

A team consists of 1 captain, 1 drummer, and 10 rowers, with 12 people as a rule, and if the minimum number of people is 10 ( 8 paddlers), you can participate in the game.

Open Competition is no age or gender restrictions

The mixed section should consist of a minimum of 4 female rowers and a maximum of 6 members. 
Support for helmsman (however, when supporting helmsman, objection to helmsman is not allowed)

\subsubsection{Competition Process}

The competition proceeds as follows.

Table 1: Competition details

\begin{tabular}{|c|c|c|c|c|}
\hline \multicolumn{2}{|l|}{ Category } & Event & Division & Match method \\
\hline General & \multirow[b]{2}{*}{$\begin{array}{c}12- \\
\text { seater }\end{array}$} & \multirow[b]{2}{*}{$500 \mathrm{~m}$} & concoction & \multirow{2}{*}{$\begin{array}{l}500 \mathrm{~m} \text { straight course } \\
\text { Preliminary, Resurrection of Losers, } \\
\text { Final } \\
* \text { Changeable depending on the } \\
\text { number of teams in the game }\end{array}$} \\
\hline Junior Division & & & open & \\
\hline
\end{tabular}

\section{Research Methods}

The hypothesis to be elucidated in this study is as follows. In a study that reported that service quality perceived by sports event participants affects service value [9] and a study that investigated the causal relationship between service quality and perceived value (Yang et al., 2010), service quality was found to have an effect on value perception. It was confirmed and the hypothesis of this study was established.

H1. The Service Responsiveness, Experience, Accessibility, Economics, and Adequacy of the competition venue perceived by the Dragon Boat Competition participants will affect their satisfaction.

H2. There will be differences in Service Responsiveness, Experience, Accessibility, Economics, and Adequacy of the competition venue factors that affect satisfaction.

\subsection{Research Subjects}

In this study, a total of 261 athletes who participated in the Busan International Dragon Boat Competition in Busan Mayor's Cup in 2019 were sampled using a convenience sampling method. Gender was 141 men (54\%), 120 women (46\%), 101 women in their 20s $(38.7 \%)$, 104 people in their 30 s to $40 \mathrm{~s}(39.9 \%)$, and 56 people in their $50 \mathrm{~s}$ or older $(21.4 \%)$. There were $117(44.88 \%)$ unmarried participants and $144(55.2 \%)$ married participants. The international department was $124(47.5 \%)$, the domestic department was 64 (24.5\%), and the citizens department was $73(28 \%)$. In terms of nationality, there were $146(55.9 \%)$ Koreans and 115 $(44.1 \%)$ foreigners. 
Table 2: Demographic statistics $(n=261)$

\begin{tabular}{|l|l|l|l|}
\hline Division & Contents & Cases & Percentage (\%) \\
\hline Gender & Man & 141 & $54 \%$ \\
& Woman & 120 & $46 \%$ \\
\hline Age & Under 30s & 101 & $38.7 \%$ \\
& 30 s-40s & 54 & $20.7 \%$ \\
& $40 s-50 \mathrm{~s}$ & 50 & $19.2 \%$ \\
& Over 50s & 56 & $21.5 \%$ \\
\hline Marital Status & Single & 117 & $44.8 \%$ \\
& Marriage & 144 & $55.2 \%$ \\
\hline Nationality & Domestic & 146 & $55.9 \%$ \\
& Foreigner & 115 & $44.1 \%$ \\
\hline Participation Type & International Part & 124 & $47.5 \%$ \\
& Domestic Part & 64 & $24.5 \%$ \\
& Citizen's Part & 73 & $28 \%$ \\
\hline
\end{tabular}

\subsection{Research Tools}

The data collection used a questionnaire, and the questionnaire consisted of four demographic characteristics and 20 competition environmental factors satisfied by the competitors of the waterfront dragon boat competition as independent variables and was presented as a five-point Likert type.

\subsection{Feasibility and Reliability of Survey Tools}

The data collected after the questionnaire survey were subjected to principal component factor analysis using varimax to derive a factor with an eigen value greater than 1.0. As a result, it was finally classified into five factors. 
Table 3: Factor analysis result for physical environmental factors

\begin{tabular}{|c|c|c|c|c|c|c|}
\hline Division & Main Contents & $\begin{array}{c}\text { Service } \\
\text { Respon } \\
\text { sivenes } \\
\quad \mathbf{S}\end{array}$ & $\begin{array}{c}\text { Experie } \\
\text { nce }\end{array}$ & $\begin{array}{c}\text { Accessibi } \\
\text { lity }\end{array}$ & $\begin{array}{c}\text { Econo } \\
\text { mics }\end{array}$ & $\begin{array}{l}\text { Adequac } \\
y \text { of the } \\
\text { competiti } \\
\text { on venue }\end{array}$ \\
\hline $\begin{array}{l}\text { Service } \\
\text { Responsi } \\
\text { veness }\end{array}$ & $\begin{array}{l}\text { Contest (Agent) } \\
\text { Knowledge } \\
\text { Contest (Agent) } \\
\text { Ease of of Conice } \\
\text { Information } \\
\text { Contest (Agent) Kindness } \\
\text { Contest Promotion }\end{array}$ & $\begin{array}{l}.777 \\
.769 \\
.760 \\
.721 \\
.673\end{array}$ & $\begin{array}{l}.381 \\
.299 \\
.115 \\
.408 \\
.101\end{array}$ & $\begin{array}{l}.240 \\
.201 \\
.153 \\
.182 \\
.193\end{array}$ & $\begin{array}{l}.110 \\
.121 \\
.362 \\
-.005 \\
.377\end{array}$ & $\begin{array}{l}.138 \\
.172 \\
.219 \\
.209 \\
.195\end{array}$ \\
\hline $\begin{array}{l}\text { Experien } \\
\text { ce }\end{array}$ & $\begin{array}{l}\text { Various Experience } \\
\text { Elements } \\
\text { Experience Element Fun } \\
\text { Experience Factor Cost } \\
\text { Experience Promotion }\end{array}$ & $\begin{array}{l}.279 \\
.263 \\
.220 \\
.362\end{array}$ & $\begin{array}{l}.801 \\
.791 \\
.706 \\
.510\end{array}$ & $\begin{array}{l}.141 \\
.208 \\
.265 \\
.198\end{array}$ & $\begin{array}{l}.156 \\
.211 \\
.318 \\
.236\end{array}$ & $\begin{array}{l}.179 \\
.118 \\
.110 \\
.356\end{array}$ \\
\hline $\begin{array}{l}\text { Accessibi } \\
\text { lity }\end{array}$ & $\begin{array}{lr}\text { Parking } & \text { Space } \\
\text { Management } & \\
\text { Public } & \text { Transport } \\
\text { Management } & \\
\text { Traffic } \quad \text { Environment } \\
\text { Safety } & \\
\end{array}$ & $\begin{array}{l}.235 \\
.248 \\
.197\end{array}$ & $\begin{array}{l}.177 \\
.240 \\
.253\end{array}$ & $\begin{array}{l}.814 \\
.775 \\
.704\end{array}$ & $\begin{array}{l}.149 \\
.203 \\
.371\end{array}$ & $\begin{array}{l}.277 \\
.202 \\
.085\end{array}$ \\
\hline $\begin{array}{l}\text { Economi } \\
\text { cs }\end{array}$ & $\begin{array}{l}\text { Adequacy of Participation } \\
\text { Cost } \\
\text { Participation } \\
\text { Benefits } \\
\begin{array}{l}\text { Participation } \\
\text { Efficiency }\end{array} \\
\end{array}$ & $\begin{array}{l}.082 \\
.280 \\
.324\end{array}$ & $\begin{array}{l}.232 \\
.321 \\
.138\end{array}$ & $\begin{array}{l}.199 \\
.199 \\
.297\end{array}$ & $\begin{array}{l}.766 \\
.721 \\
.595\end{array}$ & $\begin{array}{l}.197 \\
.094 \\
.284\end{array}$ \\
\hline $\begin{array}{l}\text { Adequac } \\
\mathrm{y} \text { of the } \\
\text { competiti } \\
\text { on venue }\end{array}$ & $\begin{array}{l}\text { Stadium Size } \\
\text { Fitness of the Stadium } \\
\text { Movement in the Stadium }\end{array}$ & $\begin{array}{l}.075 \\
.191 \\
.321\end{array}$ & $\begin{array}{l}.134 \\
.086 \\
.204\end{array}$ & $\begin{array}{l}.182 \\
.252 \\
.020\end{array}$ & $\begin{array}{l}.234 \\
.056 \\
.152\end{array}$ & $\begin{array}{l}.767 \\
.74- \\
.693\end{array}$ \\
\hline & nbach's alpha Value & .909 & .869 & .860 & .790 & .723 \\
\hline & $\begin{array}{c}\text { Eigenvalue } \\
\text { Dispersion }(\%) \\
\text { Accumulate }(\%)\end{array}$ & $\begin{array}{l}3.566 \\
19.809 \\
19.809 \\
\end{array}$ & $\begin{array}{l}2.846 \\
15.812 \\
35.621 \\
\end{array}$ & $\begin{array}{l}2.386 \\
13.255 \\
48.876 \\
\end{array}$ & $\begin{array}{l}2.269 \\
12.603 \\
61.479 \\
\end{array}$ & $\begin{array}{l}2.235 \\
12.418 \\
73.897 \\
\end{array}$ \\
\hline
\end{tabular}

As a result of deriving the relationship between the measured variables using Pearson's correlation coefficient, all were deduced to be less than .80, indicating that no multicollinearity problem occurred. 
Table 4: Correlation analysis result

\begin{tabular}{|l|l|l|l|l|l|}
\hline \multicolumn{1}{|c|}{ Measured variable } & \multicolumn{1}{c|}{$\mathbf{1}$} & \multicolumn{1}{c|}{$\mathbf{2}$} & \multicolumn{1}{c|}{$\mathbf{3}$} & \multicolumn{1}{c|}{$\mathbf{4}$} & \multicolumn{1}{c|}{$\mathbf{5}$} \\
\hline Service Responsiveness & 1 & & & & \\
\hline Experience & $.561^{* *}$ & 1 & & & \\
\hline Accessibility & $.619^{* *}$ & $.667^{* *}$ & 1 & & \\
\hline Economics & $.509^{* *}$ & $.613^{* *}$ & $.722^{* *}$ & 1 & \\
\hline $\begin{array}{l}\text { Adequacy of the } \\
\text { competition venue }\end{array}$ & $.191^{* *}$ & $.245^{* *}$ & $.204^{* *} \cdot$ & $.261^{* *}$ & 1 \\
\hline Mean & 3.213 & 3.498 & 3.565 & 3.830 & \\
\hline Standard Deviation & .911 & .845 & .747 & .895 & \\
\hline
\end{tabular}

\subsection{Research Procedures}

After explaining the contents of the survey and asking for cooperation in the purpose of the survey, the research subjects were asked to respond using the selfassessment method. The responded data was retrieved from the spot. The purpose of the analysis is to use the statistical package program for Windows, SPS20.0 version, excluding the data that has been retrieved, and then to analyze the descriptive statistics analysis, the exploratory factor analysis, and correlation analysis and the regression analysis.

\section{Results}

In this study, the physical environmental factors of the competition that domestic and foreign players who participated in the dragon boat competition are satisfied with were derived. The derived factors are divided in more detail. The differences in the satisfaction factors of the environmental factors of the competition were investigated according to the level of the participating players (international, domestic, and civil affairs) and the nationality of the participating players (Korean, foreign).

\subsection{Level of Physical Environment for Dragon Boat Competition}

Looking at the physical environmental factors of the dragon boat competition, as shown in the following <Table 5>, the Experience factor $(\mathrm{M}=3.80)$ was small but recognized the most. Next, the Adequacy of the competition venue $(M=3.79)$, Service responsiveness $(M=3.76)$, and Economics $(M=3.74)$ were recognized in order, and Accessibility ( $M=3.60)$ was found to be the lowest.

Table 5: Dragon boat physical environmental factor

\begin{tabular}{|l|l|l|}
\hline Competition Physical Environmental Factors & Average & Standard Deviation \\
\hline Service Responsiveness & 3.76 & .83 \\
Experience & 3.80 & .77 \\
Accessibility & 3.69 & .90 \\
Economics & 3.74 & .81 \\
Adequacy of the competition venue & 3.79 & .78 \\
\hline \multicolumn{2}{|l|}{$*$ The Higher the Average, the higher the quality level } \\
\hline
\end{tabular}




\subsection{Differences in the perception of physical environmental factors of the competition according to the competitors' participation}

(1) Differences in the perception of physical environmental factors in a competition based on the level of participation

As a result of conducting a one-way variance analysis, in the Adequacy of the venue $(\mathrm{F}=13.040, \mathrm{p}=.001)$ and Accessibility factors $(\mathrm{F}=10.460, \mathrm{p}=.001)$, competition participants at the international level were more than those at the domestic and citizens level. The Economics factor $(\mathrm{F}=5.137, \mathrm{p}=.01)$ also showed that participants at the international level were more satisfied than those at the domestic level.

Table 6: Differences in perception of physical environmental factors of the competition according to participation level

\begin{tabular}{|c|c|c|c|c|c|c|}
\hline Division & $\begin{array}{c}\text { Participation } \\
\text { Type }\end{array}$ & Average & $\begin{array}{l}\text { Standard } \\
\text { Deviation }\end{array}$ & $\mathbf{F}$ & Significance & Compare \\
\hline $\begin{array}{l}\text { Service } \\
\text { Responsivene } \\
\text { ss }\end{array}$ & $\begin{array}{l}\text { International } \\
\text { Part } \\
\text { Domestic Part } \\
\text { Citizen's Part }\end{array}$ & $\begin{array}{l}3.83 \\
3.67 \\
3.73\end{array}$ & $\begin{array}{l}.79 \\
.74 \\
.94\end{array}$ & .873 & .419 & Ns \\
\hline Experience & $\begin{array}{l}\text { International } \\
\text { Part } \\
\text { Domestic Part } \\
\text { Citizen's Part }\end{array}$ & $\begin{array}{l}3.91 \\
3.73 \\
3.69\end{array}$ & $\begin{array}{l}.66 \\
.79 \\
.90\end{array}$ & 2.204 & .112 & Ns \\
\hline Accessibility & $\begin{array}{l}\text { International } \\
\text { Part } \\
\text { Domestic Part } \\
\text { Citizen's Part }\end{array}$ & $\begin{array}{l}3.79 \\
3.18 \\
3.64\end{array}$ & $\begin{array}{l}.65 \\
1.04 \\
1.03\end{array}$ & 10.460 & .000 & $1,2>3$ \\
\hline Economics & $\begin{array}{l}\text { International } \\
\text { Part } \\
\text { Domestic Part } \\
\text { Citizen's Part }\end{array}$ & $\begin{array}{l}3.85 \\
3.47 \\
3.79\end{array}$ & $\begin{array}{l}.73 \\
.86 \\
.85\end{array}$ & 5.134 & .007 & $1>2$ \\
\hline $\begin{array}{l}\text { Adequacy of } \\
\text { the } \\
\text { competition } \\
\text { venue }\end{array}$ & $\begin{array}{l}\text { International } \\
\text { Part } \\
\text { Domestic Part } \\
\text { Citizen's Part }\end{array}$ & $\begin{array}{l}3.96 \\
3.38 \\
3.88\end{array}$ & $\begin{array}{l}.71 \\
.67 \\
.86\end{array}$ & 13.040 & .000 & $1,2>3$ \\
\hline
\end{tabular}

$* p<.05, * * * p<.001$

(2) Differences in the perception of physical environmental factors of the competition according to the nationality of the participating countries.

As a result of conducting an independent sample T-test analysis, the difference in perception of physical environmental factors of the competition according to the nationality of the participants showed that foreign athletes had more accessibility to the venue $(\mathrm{t}=-3.634, \mathrm{p}=.001)$ and economics $(\mathrm{t}=-1.969, \mathrm{p}=.05)$ showed more satisfaction. 
Table 7: Differences in the perception of physical environmental factors of the competition according to the nationality of the participating countries.

\begin{tabular}{|c|c|c|c|c|c|c|}
\hline Division & $\begin{array}{c}\text { Participation } \\
\text { Type }\end{array}$ & Average & $\begin{array}{l}\text { Standard } \\
\text { Deviation }\end{array}$ & $\mathbf{F}$ & Significance & Compare \\
\hline $\begin{array}{l}\text { Service } \\
\text { Responsive } \\
\text { ness }\end{array}$ & $\begin{array}{l}\text { Domestic } \\
\text { Foreigner }\end{array}$ & $\begin{array}{l}3.71 \\
3.82\end{array}$ & $\begin{array}{l}.84 \\
.81\end{array}$ & .004 & .956 & Ns \\
\hline Experience & $\begin{array}{l}\text { Domestic } \\
\text { Foreigner }\end{array}$ & $\begin{array}{l}3.73 \\
3.89\end{array}$ & $\begin{array}{l}.84 \\
.67\end{array}$ & 2.788 & .096 & Ns \\
\hline $\begin{array}{l}\text { Accessibilit } \\
\mathrm{y}\end{array}$ & $\begin{array}{l}\text { Domestic } \\
\text { Foreigner }\end{array}$ & $\begin{array}{l}3.43 \\
3.81\end{array}$ & $\begin{array}{l}1.04 \\
.65\end{array}$ & 25.992 & .000 & $2>1$ \\
\hline Economics & $\begin{array}{l}\text { Domestic } \\
\text { Foreigner }\end{array}$ & $\begin{array}{l}3.66 \\
3.85\end{array}$ & $\begin{array}{l}.86 \\
.74\end{array}$ & 4.699 & .031 & $2>1$ \\
\hline $\begin{array}{l}\text { Adequacy } \\
\text { of the } \\
\text { competition } \\
\text { venue }\end{array}$ & $\begin{array}{l}\text { Domestic } \\
\text { Foreigner }\end{array}$ & $\begin{array}{l}3.65 \\
3.97 .\end{array}$ & $\begin{array}{l}.80 \\
.72\end{array}$ & .114 & .736 & ns \\
\hline
\end{tabular}

$* p<.05, * * * p<.001$

* Domestic Athletes $=$ Korean, Foreigner $=$ Chinese, Hong Kong, Philippines Multinational Players

\section{Discussion}

The purpose of this study was to understand the relationship between the factors of Service Responsiveness, Experience, Accessibility, Economics, and Adequacy of the competition venue of the Dragon Boat Festival, and to increase the satisfaction of the participants in the festival to understand the sustainability of the Busan Dragon Boat Festival as a marine sports festival.

The physical environmental factors of the competition satisfied by the dragon boat competition held in the waterfront showed that the athletes in the international division recognized the suitability and accessibility of the stadium higher than those in the civil and domestic sectors, and that the economic factors showed that the participants in the international division were more likely to recognize it than those in the domestic division. This suggests the need for a discriminatory approach that takes into account the level of participants participating in the competition. Specifically, it presents a multi-dimensional strategy in consideration of the competitors' performance, understanding of the competition, and expected factors, which means a justification for holding a more satisfying competition. Yang et al. (2010) supported the results of this study by reporting that the higher the level of participation of athletes, the more sensitive the level of performance and the quality of service of participating in the competition. For most international competitions, various approaches are attempted for the convenience and hospitality of foreign athletes. However, the inherent key factors, namely the appropriateness and accessibility of the venue, are perceived to be more sensitive than other additional 
factors, which are considered environmental factors to be considered when hosting international competitions. On the other hand, the civic department, which is equivalent to amateur form, also participates in leisure form, so it is judged that the desire to participate in the competition is relatively different from those of professional level international division.

Thus, the organizers of the competition will have to apply discriminatory marketing, including the provision of schedules and time-separation, considering the level of participants in the competition, such as the Masters and the Open. Second, the physical environmental factors for dragon boat competition satisfaction held in the waterfront showed that foreign athletes perceived higher access to the venue and economic feasibility than domestic players. This is the result of the event organizers providing separate services to participants. Dragon boat competitions utilizing waterfront are festive events that have been activated in Asian countries such as China (An, 2016), while Korea is just known and is an area of water leisure that is expanding around some areas. Therefore, there is a limitation that has not spread to sports for daily life other than club-oriented activities. Therefore, it is judged that those who participate in the competition from a distance are relatively dissatisfied with the accessibility of the competition, and that there is also a limit to the perceived inconvenience of a discriminatory marketing approach to foreign and domestic players. Therefore, the association that organizes the event should plan and operate the event, while establishing a long-term plan to expand the base of the dragon boat, as well as continuing discussions with the competent authorities in charge of it. Different types of events have unique characteristics for each event. For planning and executing events, a clear preliminary analysis is needed for participants in the competition. Based on this, the provision of services suitable for the level of participants and the composition of the physical environment of the competition will lead to recognition of the competition as well as future reparticipation. Therefore, careful consideration needs to be paid to the organizers' expertise, systematic system and staff selection and education for the performance of services provided at the competition (Ryu et al., 2016).

The implications derived based on the above research results present practical meanings to various organizations hosting and conducting actual competitions. When hosting and hosting a competition, it will be possible to proactively explore the connectivity of the sports events and regions in question, at the same time to consider the benefits and benefits of the competitors through the competition, and also to create an emotional consensus among the local residents to hold a more successful event or competition.

According to the Korea Culture and Tourism Institute, 886 festivals were held in 2018. Indeed, in order to establish itself as a successful festival in the flood of festivals, differentiation will be essential, and for that differentiation, it can be interpreted as meaning that it is necessary to clarify the original purpose and theme 
of the festival contents and promote it centering on it. In order to apply these results to the field, it is necessary to sufficiently promote the history and meaning of dragon boats rather than similar programs when planning a festival, and to allow festival participants to understand the meaning.

Participants of the Dragon Boat Festival show the characteristics of participating in the festival together after they have already formed a social relationship rather than forming a new social relationship through the festival. This is the need to promote through media that can be easily accessed by clubs or family members based on established relationships, and it will be important to provide programs and facilities that satisfy these groups during participation. In order to differentiate the Dragon Boat Festival, it means that it must provide a unique experience that cannot be experienced at other festivals, and the possibility of differentiation can be explored by giving historical background and meaning.

\section{Conclusion}

This study explores the physical environmental factors that the athletes who participated in the dragon boat competition held in a water-friendly space are satisfied with, and analyzes the differences according to the participation level and the participating nationality in order to find out the differences in the physical environmental factors according to the athletes participating in the competition. Based on the above results, the following conclusions were obtained.

Through this study, the information that can be used in the marketing aspect and the information actually needed by the water sports event organizer and person in charge are as follows. First, for foreign athletes participating in water sports events, it is necessary to consider the ease of participation procedure and suitability of the stadium as external and internal factors, and the expertise of well-educated interpreters and staff is required. The higher the level of athletes who participated in the waterfront dragon boat competition (international players), the higher the adequacy, cost of participation, and accessibility of the venue, and the higher the foreign players' benefits and convenient accessibility to the competition (Kim et al., 2020). Second, the factors that must be maintained for foreign athletes are the internal elements of the competition, such as movement and safety in the stadium, efficient game progress, and service response of staff. Third, the factors that should be prioritized for foreign players are factors related to preliminary preparation for participation in the game (participation cost benefit, online registration system and prior publicity), and sufficient space, traffic safety, and facility usage fees. In particular, in order to induce foreign players to participate, it is necessary to minimize the discomfort of participating players by sharing an organic relationship with the relevant national association. Fourth, factors that indicate satisfaction should be based on external factors such as diversity of experience, experience distance in the stadium, and fun of experience factors, and self-movement. 
Therefore, in-depth efforts from the organizers of the event will be needed to prevent these factors from being disturbed.

The higher the level of players participating in the water-friendly dragon boat competition (international division players), the more appropriate, participation cost and accessibility of the venue were recognized, and foreign players also recognized the benefits and convenient accessibility higher than the participation cost of the competition. Therefore, the organizers of the competition should prepare a clear process for the management of the competition and at the same time establish a response strategy that considers the level of participants. Based on the above conclusion, a systematic marketing plan should be prepared in consideration of the level of participation, nationality, and characteristics of various participants in future dragon boat competitions. Moreover, efforts should be made to develop or apply physical environmental factors that can reflect the characteristics of the area representing the water-friendly space and reflect the event.

At the same time, at the academic level, it should be expanded to a variety of studies, such as examining the level of participation and the difference between Koreans and foreigners, understanding the environmental factors of the competition according to the participation experience and clarifying the importance of the environmental factors provided at the same time. In addition, it is believed that it can be extended to research on the dragon boat competition held in a water-friendly space, the suitability of the local space, and the expected effects of the local community through the event. It goes without saying what is needed, and it is a natural concept that marine leisure sports will be activated, and it can be said that it is very natural (Baek et al., 2021)

It is difficult to generalize the results of this study to the overall Dragon Boat Festival because only the participants of the Dragon Boat Festival were targeted. Convergence is necessary to create new knowledge and information based on knowledge of various disciplines and to creatively solve new problems (Kim, 2020). In order to compensate for this problem, it is necessary to expand the subject in subsequent studies. In this study, Service Responsiveness, Experience, Accessibility, Economics, and Adequacy of the competition venue were verified, but in order to verify the nature of the dragon boat competition as a marine sports festival more diversely, it is necessary to use additional variables.

\section{References}

An, B. (2016). An Importance and Satisfaction Analysis for Improvement Efficiency Use of Waterfront - A Focus on the Waterfront Analysis for Domestic and Foreign Dragon Boat Festival -. Journal of the Korean Institute of Landscape Architecture, 4(4), 86-99. 
Baek H. K., Hong K. H., and Choi H. (2021). A Marketing Plan Proposal through Consumer Analysis: Focusing on the Scuba Diving Market. Journal of Advanced Researches and Reports, 1(1), 1-8.

Carman, J. M. (1990). Consumer Perceptions of Service Quality: an Assessment of the SERVQUAL Dimensions. Journal of Retailing, 66, 33-55.

Cho, W. J. (2013). Analyses of Sustainable Development Strategies of Marine Sport Evnets Using AHP. Journal of Sport and Leisure Studies, 52, 197-210.

Choi, S. G. and Ok, G. (2013). Dragon Boat for the introduction and spread of the discourse in Korea. Journal of Marine Sport Studies, 3(2), 1-13.

Dabholkar, P. A. (1996). Consumer Evaluations of New Technology - based Self Service Options: an Investigation of Alternative Models. International Journal of Research in Marketing, 66, 33-55.

Kim C. (2020). Recognition and Demand for Creative Confluence Education of Education Major Students. Journal of Human-centric Research in Humanities and Social Sciences, 1(2), 21-26.

Kim J. B. and Cho W. J. (2014). The Effects of Marine Sport Event's Appraisal Attributes on City Marketing Asset and City Marketing Effectiveness. Korean Society for Sport Management, 19(6), 1-15.

Kim K. B., Park J. Y., and Chung H. (2020). A Study on the Factors of Satisfaction with the Competition Environment Using the Dragon Boat Race's Natural Tourist Site - The Case of Busan Dragon Boat Competition. Journal of Human-centric Research in Humanities and Social Sciences, 1(2), 13-20.

Kim, M. J. and Choi, I. S. (2010). A Study on the Perceptual Experience of Waterfront Space in the City for Waterfront Environment. Journal of the Korean Society for Space Design, 7 (4), 49-57.

Ko, S. H. and Park, E.S. (2011). Influence on the Destination Attractiveness on Perceived Value, Satisfaction, Loyalty among Japanese Tourists. The Korea Contents Society, 11(7), 467-477.

Lee, B. C. and Yim, Y. S. (2019). An Analysis on Relationship between Participation Motives in Marine Sports and Leisure Activity Satisfaction as a Family Leisure. The Journal of Maritime Business, 43, 167-183. 
Lee, J. H. (2010). Waterfront and Port Waterfront. Korea Maritime Institute, 21(7), 160-174.

Min, D. S., Ko, J. M. and Lee, W. Y. (2020). Examining the Structural Relationships between International Sporting Event Experience, Perceived Value, Destination Image, Satisfaction and Behavioral Intention. Korean Alliance for Health. Physical Education, Recreation, and Dance, 59(3), 243-261.

Ryu, D. S., Kim, J. G. and Kang, H. M. (2008). Relationship Between Participants' Awareness of the Quality of Service and Willingness to Re-participate in Futsal Events as a Leisure Activity. Journal of the Korea Association of Leisure and Recreation, 32(1), 49-59.

Yang, E. S., Kim, S. J., and Kim, S. D. (2010). The Differences in the Level of Service Quality of the Competition According to the Participation of Dance Sports Players. Korean journal of physical education, 49(1), 255-265. 